\title{
Preliminary Study of Alkali Activation of Basalt: Effect of $\mathrm{NaOH}$ Concentration on Geopolymerization of Basalt
}

\author{
Mohamed El-Shahte Ismaiel Saraya ${ }^{1}{ }^{*}$, Ezzat El-Fadaly ${ }^{2}$ \\ ${ }^{1}$ Department of Chemistry, Faculty of Science, Al-Azhar University, Cairo, Egypt \\ ${ }^{2}$ Environmental Studies and Research Institute, Sadat City University, Sadat City, Egypt \\ Email: moham edsaraya37@gmail.com
}

How to cite this paper: Saraya, M.E.-S.I. and El-Fadaly, E. (2017) Preliminary Study of Alkali Activation of Basalt: Effect of $\mathrm{NaOH}$ Concentration on Geopolymerization of Basalt. Journal of Materials Science and Chemical Engineering, 5, 58-76. https://doi.org/10.4236/msce.2017.511006

Received: October 6, 2017

Accepted: November 25, 2017

Published: November 28, 2017

Copyright ( 92017 by authors and Scientific Research Publishing Inc. This work is licensed under the Creative Commons Attribution International License (CC BY 4.0).

http://creativecommons.org/licenses/by/4.0/

\begin{abstract}
The main objective of this study is to examine the possibility of using fresh basalt powder in the preparation of geopolymer pastes. Four $\mathrm{NaOH}$ concentrations of 2.5, 5, 7.5 and $10 \mathrm{M}$ were used to alkali activation of basalt. In addition, effect of curing temperature at ambient, $45^{\circ} \mathrm{C}$ and $65^{\circ} \mathrm{C}$ were studied. The geopolymer pastes were investigated using FTIR, XRD and SEM-EDS techniques as well as compressive strength up to 90 days. The results were shown the compressive strength of prepared geopolymer increased with concentration of alkali activator up to 90 days. On the other hand, the compressive strength of prepared geopolymer pastes were improved with increased curing temperature. The results showed that there was a change in the chemical and mineral structure, due to the reaction of the sodium hydroxide with the different minerals of the basalt. In addition, the $\mathrm{Na} / \mathrm{Al}$ and $\mathrm{Si} / \mathrm{Al}$ ratios were completely different from that of the raw basalt. The geopolymerization reactions occurred at the surface basalt and the unreacted basalt particles actually play a supporting role in the geopolymer properties.
\end{abstract}

\section{Keywords}

Fresh Basalt, Alkali Activation, Geopolymer, FTIR, XRD, EDS-SEM

\section{Introduction}

Cement clinker industry is one of the largest industries consuming raw materials and energy in addition to its contribution to many environmental missions [1]. In spite of the pozzolanic materials improve the durability properties of blended cement, it may be case in long setting times and lower early strengths [2]. 
Chemical methods are the most effective and inexpensive methods to increase the efficiency of the pozzolanic materials.

Davidovits was prepared geopolymer materials in the early 1970s, they are a class of largely X-ray amorphous aluminosilicate materials. Generally, it is prepared at ambient or a little elevated temperature by reaction of a solid aluminosilicate material with a concentrated alkali hydroxide solution or alkali metal silicate [3]. According to Davidovits, the empirical chemical formula of geopolymers also known as poly(sialates) is as follows: $\mathrm{Mn}\left\{\left(\mathrm{SiO}_{2}\right) \mathrm{zAlO}_{2}\right\} \mathrm{n} \mathrm{wH}_{2} \mathrm{O}$ where $\mathbf{M}$ is a cation, $\mathbf{n}$ the degree of polycondensation, $\mathbf{w}$ the number of water molecules and $\mathbf{z}$ equals to 1,2 or 3 . The structure of basic binding matrix in geopolymer is similar to synthetic or natural crystalline zeolites but their microstructure is amorphous to semi-crystalline [4].

The geopolymerization process depends on many factors including chemical and mineralogical compositions, particle size distribution and specific surface area of the raw material, $\mathrm{Si} / \mathrm{Al}$ molar ratio, the water content, the alkali content and the curing conditions [5]. The mechanism of geopolymer formation includes an initial dissolution step, where the alkali solution not only hydrolyzes the surface of mineral particles, but also dissolves a small amount of $\mathrm{Al}$ and $\mathrm{Si}$ species. These dissolved species react with already dissolved silicate ions forming a gel that is transformed into the final structure trough crystallization or another dissolution process.

The unique properties of geopolymer such as fire and chemical resistance; low thermal conductivity and low shrinkage [6], make it suitable for many applications as in building materials and encapsulation of hazardous waste [7] [8].

Many previous works have reported the formation of geopolymer materials from calcined clays [9] [10], granulated blast furnace slag and fly ash as industrial by-products or wastes [11] [12], volcanic ashes [13] [14] [15], ground perlite [16], ground aplite rock [17], granite waste [18], Taftan and esite and Shahindej [19], alkali-feldspars [20] [21], a pumice-type natural pozzolan [22], basaltic ash [23].

Basalts are containing intermediate plagioclase feldspars (An 35 - 60) and augitic pyroxene as essential minerals with or without olivine, beside magnetite and variable amounts of glass. In Egypt, there are large fields of basaltic rocks that are used as concrete aggregate. In addition, there are a great amount of basalt powder is produced as byproducts of stone crushing. In many studies, it was found that basalt activity is affected by surface area, volcanic glass content, $\mathrm{SiO}_{2}$ content and alteration minerals [24] [25] [26] [27] [28]. Marfil et al. [29] measured the reactivity of seventeen basalt samples and concluded that reactivity is closely related to the dissolved silica contributed by the deleterious mineralogical components of basaltic rocks.

This work aims to study the potential use of basalt as a raw material for preparing geopolymer materials and study the effect of sodium hydroxide concen- 
tration and curing temperature on the properties of alkali-activated basalt-based geopolymers up to 90 days.

\section{Material and Methods}

The materials used in this investigation were basalt powder, sodium hydroxide (99\%) and distilled water was used for preparation of alkali activators. The basalt powder used for this study conforms to ASTM C 618 as the pozzolana material Table 1.

The Si/Al ratio was kept constant for all mixtures, also water/solid ratio = 0.35 . Table 2 showed the amounts of each material used for synthesis the geopolymers. Different amounts of solid sodium hydroxide were dissolved in distilled water to obtain concentrations $2.5,5,7.5$ and $10 \mathrm{M} / 1$ to be used as activator for basalt. These solutions were used for alkali activation of basalt. The solution was covered and sealed to minimize carbonation of solution for 24 hours, which allowed the solution to cool down to room temperature. The mixture proportions of prepared geopolymer pastes are shown in Table 3. The basalt powder mixed for 20 minutes with the activator solution. The fresh geopolymer paste was poured in 3 layers into $2 \times 2 \times 2$ inch stainless steel molds to determine its compressive strength, vibrated for 30 seconds with a vibrating machine, filled completely and vibrated for 30 seconds for all samples to release any residual air bubbles. The specimens were covered with plastic sheet to inhibit loss of moisture and then placed in an oven.

After mixing and vibration, the mix was placed into curing room, which was set at $25^{\circ} \mathrm{C}$ and $100 \%$ relative humidity. After 24 hours in the curing room, specimens were demolded and placed back into the curing room. The samples were kept at curing temperature, ambient temperatures, $45^{\circ} \mathrm{C}$ and $65^{\circ} \mathrm{C}$ until testing, Figure 1.

Table 1. Chemical and physical properties of pozzolana according to ASTM C618.

\begin{tabular}{ccccccc}
\hline Items & $\begin{array}{c}\mathrm{SiO}_{2}+\mathrm{Al}_{2} \mathrm{O}_{3} \\
+\mathrm{Fe}_{2} \mathrm{O}_{3}\end{array}$ & $\begin{array}{c}\text { Moisture } \\
\text { content }(\%)\end{array}$ & $\begin{array}{c}\text { Loss on } \\
\text { ignition }(\%)\end{array}$ & $\begin{array}{c}\text { Specific } \\
\text { gravity }\end{array}$ & $\begin{array}{c}\text { Average particle } \\
\text { size }(\mu \mathrm{m})\end{array}$ & $\begin{array}{c}\text { Blaine fineness } \\
\left(\mathrm{cm}^{2} / \mathrm{g}\right)\end{array}$ \\
\hline $\begin{array}{c}\text { Measured } \\
\text { values }\end{array}$ & 80.00 & 0.9 & 1.5 & 3.2 & 11.5 & 3200 \\
\hline
\end{tabular}

Table 2. Initial molar ratios of $\mathrm{Al}_{2} \mathrm{O}_{3}, \mathrm{SiO}_{2}, \mathrm{Na}_{2} \mathrm{O}$ and $\mathrm{CaO}$ in mixtures.

\begin{tabular}{ccccccc}
\hline Mix no. & Mix symbol & $\mathrm{SiO}_{2} / \mathrm{Al}_{2} \mathrm{O}_{3}$ & $\mathrm{Na}_{2} \mathrm{O} / \mathrm{Al}_{2} \mathrm{O}_{3}$ & $\mathrm{Na}_{2} \mathrm{O} / \mathrm{SiO}_{2}$ & $\mathrm{Ca} / \mathrm{Al}$ & $\mathrm{Si} / \mathrm{Ca}$ \\
\hline 1 & $\mathrm{BS} 1$ & 3.3940 & 0.3222 & 0.0949 & 0.66 & 5.10 \\
2 & $\mathrm{BS} 2$ & 3.3940 & 0.4499 & 0.1325 & 0.66 & 5.10 \\
3 & $\mathrm{BS} 3$ & 3.3940 & 0.5775 & 0.1701 & 0.66 & 5.10 \\
4 & $\mathrm{BS} 4$ & 3.3940 & 0.7052 & 0.2077 & 0.66 & 5.10 \\
\hline
\end{tabular}


Table 3. Mix proportions of geopolymer pastes.

\begin{tabular}{|c|c|c|c|c|}
\hline Mix no. & Mix symbol & BS (g) & $\mathrm{L} / \mathrm{B}$ ratio & $\mathrm{NaOH}(\mathrm{M})$ \\
\hline 1 & BS1 & 100 & 0.35 & 2.5 \\
\hline 2 & BS2 & 100 & 0.35 & 5.0 \\
\hline 3 & BS3 & 100 & 0.35 & 7.5 \\
\hline \multirow[t]{6}{*}{4} & BS4 & 100 & 0.35 & 10 \\
\hline & $\begin{array}{c}\text { Basalt } \\
\text { powder }\end{array}$ & $\mathrm{H}_{2} \mathrm{O}$ & $\begin{array}{c}\text { Alkali } \\
\text { solution }\end{array}$ & \\
\hline & & $\begin{array}{l}\text { Geopolymer } \\
\text { slurry }\end{array}$ & & \\
\hline & & Casting & & \\
\hline & & $\begin{array}{c}\text { Curing } \\
\text { at } 25,45 \text { and } 65^{\circ} \mathrm{C}\end{array}$ & & \\
\hline & & Testing & & \\
\hline
\end{tabular}

(a)

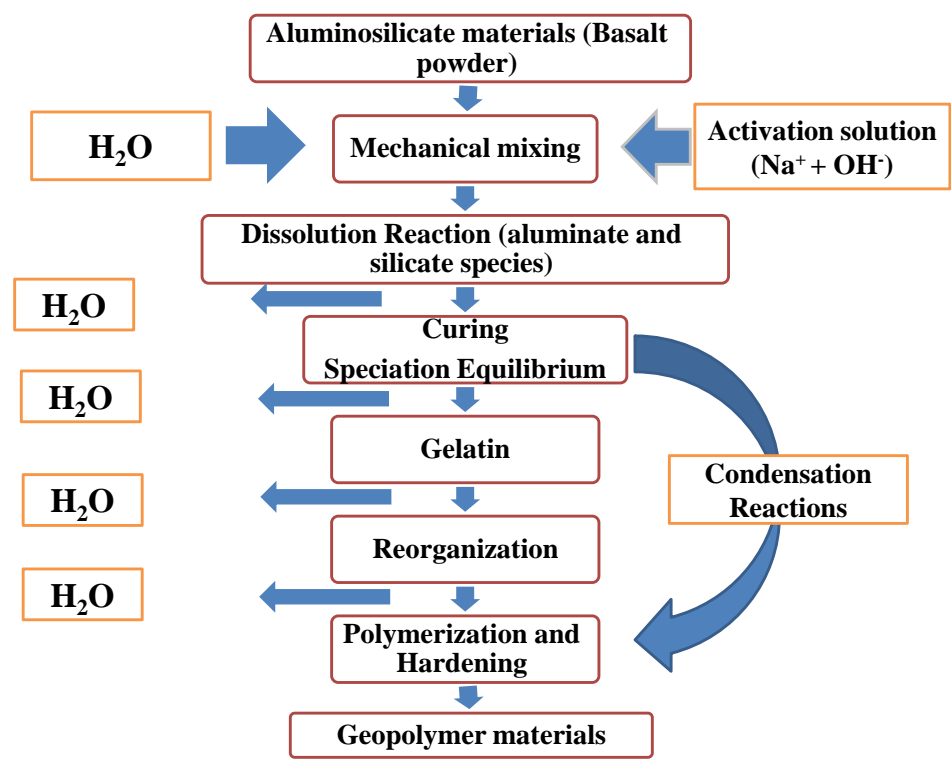

(b)

Figure 1. (a) Experimental design of fabricating the prepared basalt based geopolymers; (b) Schematic diagram provide description to the geopolymerization reaction. 
The compressive strength measurement was carried out according to the ASTM C109/C109 M-05 [30]. The compressive strength of the geopolymer pastes were measured for all mixtures after 3, 7, 28 and 90 days and cured at $25^{\circ} \mathrm{C}, 45^{\circ} \mathrm{C}$ and $65^{\circ} \mathrm{C}$. After measurement of the compressive strength, fragments of geopolymer paste samples were treated with a mixture of ethanol and acetone for $30 \mathrm{~min}$ so that its reactivity would decrease [23] [31]. All samples were air dried and ground into fine powder and then kept for analyses.

The XRD measurements were completed by diffractometer XRD 7000 (M/S. Shimadzu Instruments, Japan). The Fourier transform infrared spectroscopy (FT-IR) spectra of the products were recorded using Perkin Elmer 880 FT-IR spectrometer with the $\mathrm{KBr}$ pellet method. Finally, the microstructure of basalt-based geopolymers were studied for some selected samples by Scanning Electron Microscopy (SEM), a JEOL JSM 6360 DLA, Japan and the SEM-EDS analysis by FEI Company, Quanta FEG250, Holland.

\section{Results and Discussion}

\subsection{Compressive Strength}

Figure 2(a) shows the compressive strength of alkali activate basalt pastes cured at ambient temperature and $45^{\circ} \mathrm{C}$. The compressive strength was increased with curing time up to 90 days and increasing of molarity of activator, while BS4 paste $(10 \mathrm{M} \mathrm{NaOH})$ could not be measured still stick and not hard enough to be tested. This attributed to dissolution of silica and alumina in a highly concentrated $\mathrm{NaOH}$ solution. Sodium hydroxide plays an important role in the process of the geopolymerization, since in the initial periods it dissolves and disassembles the silica and aluminum ions of the basalt and works to equalize and balance the charge of the geopolymer network in later ages.

Dali Bondor et al. [19] reported the alkali activated pastes require time or/and an elevated temperature for increasing the strength especially in concentration higher than 7.5 M. Figure 2(a) illustrates the compressive strength of geopolymer pastes cured at $45^{\circ} \mathrm{C}$. It is clear the compressive strength increased with temperature for all samples. Since at higher temperatures, the geopolymerization process is high and so the amount of reaction products increases [32]. Meanwhile 3-day compressive strength of geopolymer pastes cured at $45^{\circ} \mathrm{C}$ was increased than that cured at ambient temperature by $50 \%, 33 \%, 3 \%$ and $28.5 \%$ for BS1, BS2 and BS3 pastes, respectively. The best alkali activated samples were obtained using $10 \mathrm{M} \mathrm{NaOH}$ after curing for 90 days, $4 \mathrm{MPa}$.

Figure 2(b) shows the compressive strength of alkali activated basalt paste cured at $25^{\circ} \mathrm{C}, 45^{\circ} \mathrm{C}$ and $65^{\circ} \mathrm{C}$ up at 90 days. The elevated temperature enhances the formation of hard structure. As seen, the compressive strength of basalt geopolymer increased with temperature and all pastes explained the highest value of compressive strength at $65^{\circ} \mathrm{C}$. This is due to the better distribution of the granules basalt in the geopolymeric binder, which give a dense composite plays an important role in the compressive strength of basalt-based geopolymer [33]. 


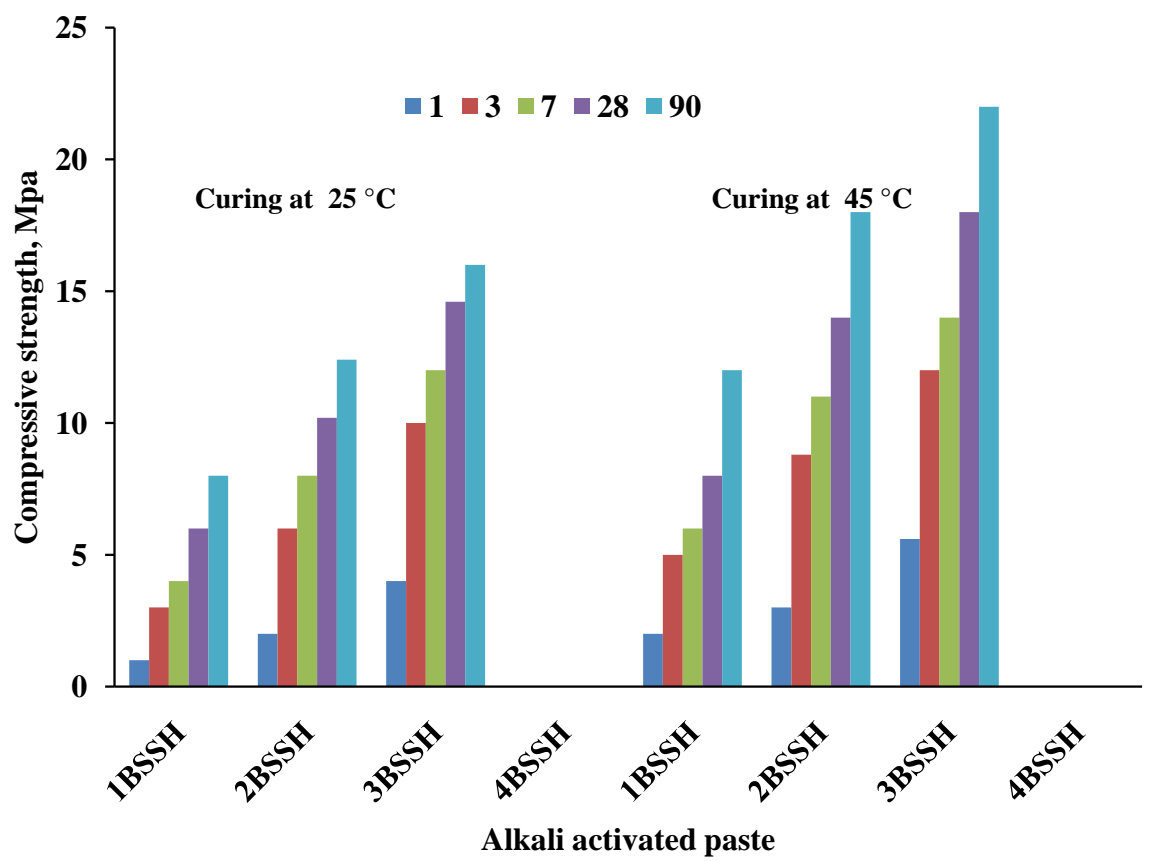

(a)

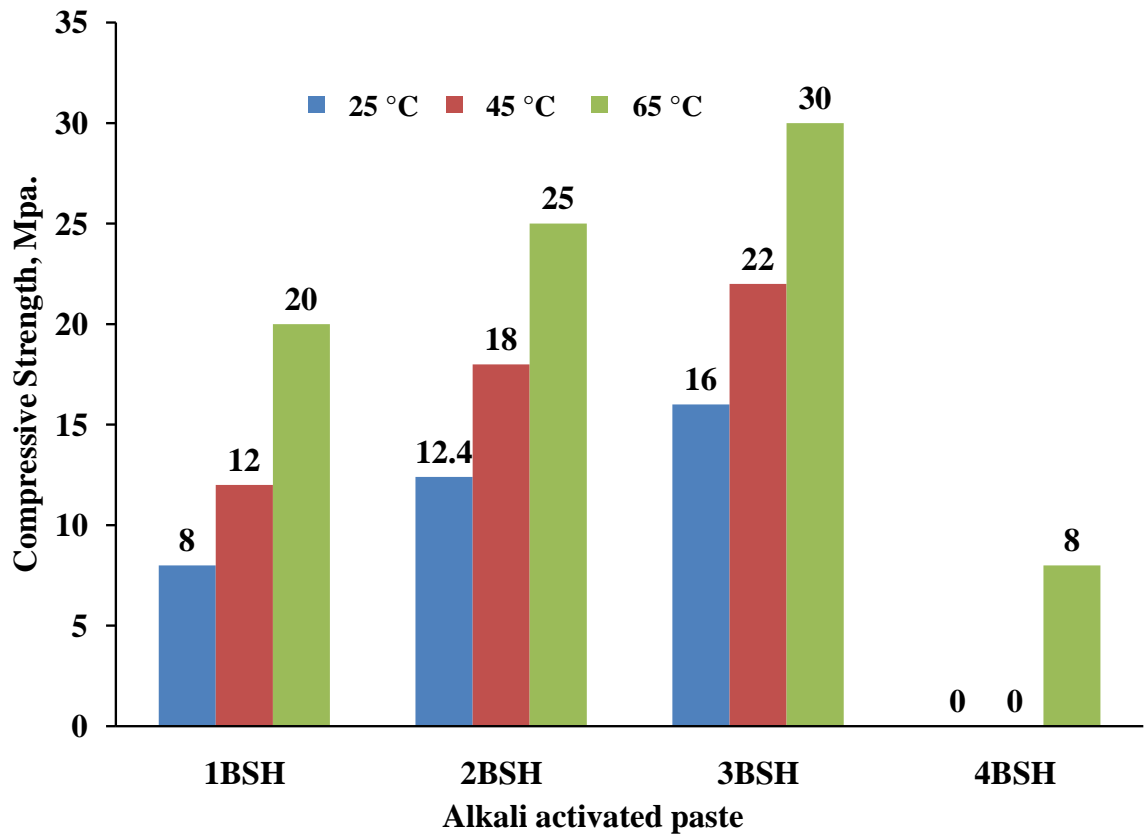

(b)

Figure 2. Compressive strength of basalt-based geopolymer. (a) cured at $25^{\circ} \mathrm{C}$ and $45^{\circ} \mathrm{C}$ for 90 day; (b) cured at different temperature for 90 day.

\subsection{FT-IR Analysis}

Figures 3(a)-(d) show the FTIR spectra of geopolymer samples cured at ambient temperature and $45^{\circ} \mathrm{C}$ for 1 and 90 days. The IR spectra of the basalt shows band near $1016 \mathrm{~cm}^{-1}$ and at $1143 \mathrm{~cm}^{-1}$ due to asymmetric stretching of Si-O while band at $458 \mathrm{~cm}^{-1}$ to in-plane $\mathrm{Si}-\mathrm{O}$ bending in $\mathrm{SiO}_{4}$ [34]. In addition, bands at around 772, 579, 537 and $439 \mathrm{~cm}^{-1}$ are related to Al-Si minerals [35]. 


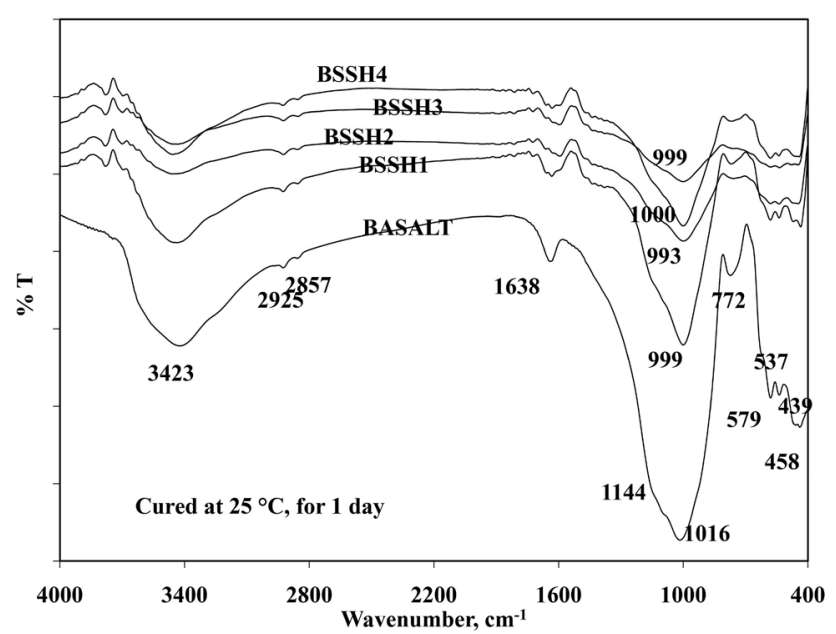

(a)

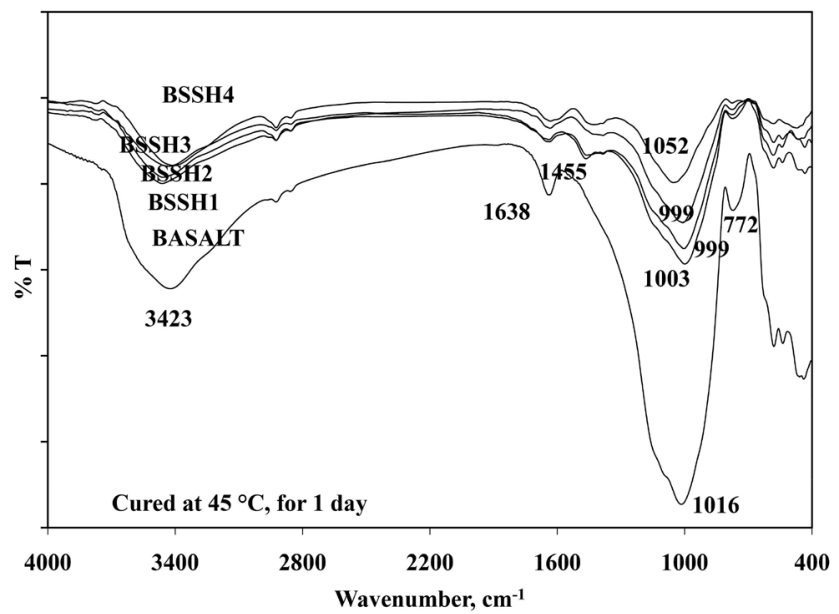

(c)

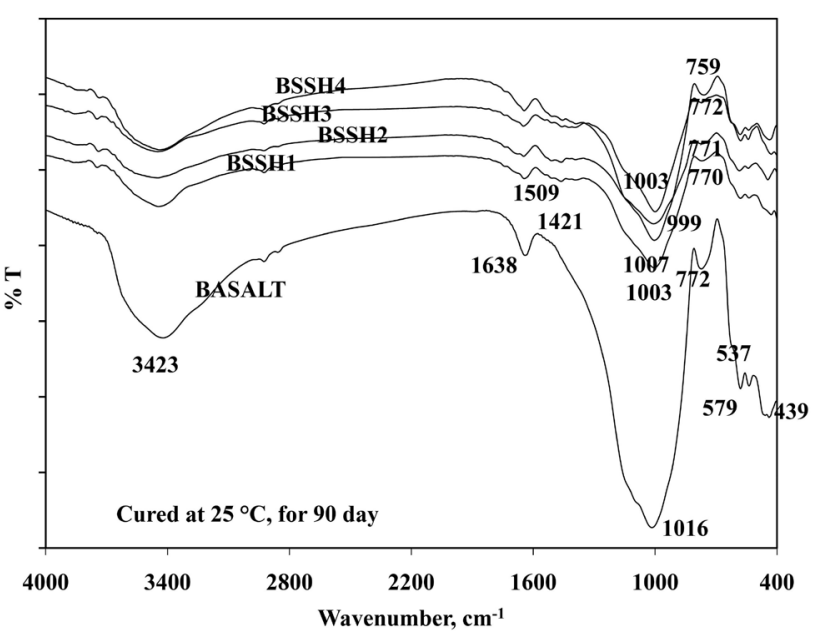

(b)

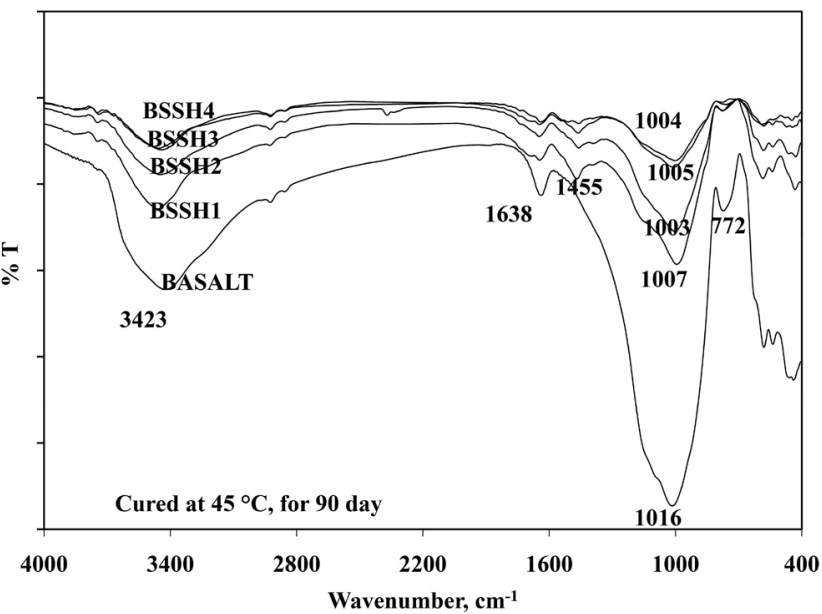

(d)

Figure 3. Infrared spectra of basalt-based geopolymer cured at $25^{\circ} \mathrm{C}$ and $45^{\circ} \mathrm{C}$ for 1 and 90 day.

The main band of basalt at $1016 \mathrm{~cm}^{-1}$ was shifted to lower wave numbers, 999, 993, 999 and $1000 \mathrm{~cm}^{-1}$ for BS1, BS2, BS3 and BS4 pastes, respectively. This shift indicates the formation of an amorphous aluminosilicate phase [36]. Further, new bands at 3423,1638 and $1540 \mathrm{~cm}^{-1}$ were appeared these bands are associated to -OH, $\mathrm{H}_{2} \mathrm{O}$ bending and asymmetric stretching of carbonate, respectively.

At 90 day, Figure $3(\mathrm{~b})$, the main peak at around $1000 \mathrm{~cm}^{-1}$ was shifted to a higher frequency but the sample BS4 paste did not change. The intensity increase of this band is indication to an increase of a mean chain length of aluminosilicate polymers [37]. The weak band at $1144 \mathrm{~cm}^{-1}$ and at $1016 \mathrm{~cm}^{-1}$ in geopolymer pastes spectrum give the evidence of unreacted basalt in geopolymeric binder.

Figure 3(c), Figure 3(d) display IR spectra of basalt-based geopolymers pastes cured at $45^{\circ} \mathrm{C}$ up to 1 and 90 days. As seen in all spectra, the band at 1000 was shifted to lower wave numbers with alkali concentration and curing time, but larger than that cured at ambient temperature. This is attributed to effect of temperature on the rate of geopolymerization reactions that result in the forma- 
tion of a more oriented molecular aluminosilicate gel, [38], besides increased the intensity of band at $1000 \mathrm{~cm}^{-1}$. In addition, the bands at 772, 579, 537 and 439 $\mathrm{cm}^{-1}$ decreased or disappeared as concentration of activator increased and curing time.

Figure 4 shows the IR spectra analysis of prepared geopolymers BS1, BS2, BS3 and BS4 cured at different temperature. As seen from Figure 4, the band at 1000 $\mathrm{cm}^{-1}$ for all geopolymer samples shifted to a high frequency at $45^{\circ} \mathrm{C}$ than that $25^{\circ} \mathrm{C}$ and at $65^{\circ} \mathrm{C}$. This indicates the curing temperature has strong influence on the rate of geopolymerization reactions, whereas the dissolution and polymerization (condensation). Besides, the intensity of this band decreased with increasing temperature, which indicates the minerals in the basalt change.

To better understanding of the FTIR spectra, the bands in the region between 1400 and $800 \mathrm{~cm}^{-1}$ of FTIR spectra was deconvoluted with computer software to determine and quantify the phases sharing to form the T-O bond asymmetric stretching band. A gaussian function was used for fitting of the bond. The basic concept in the fitting procedure was to lower the number of the component bands and retaining a regression coefficient $r^{2}$ near to 1 . In this study, the band for the basalt included four signals, at the following positions: $881 \mathrm{~cm}^{-1}, 979$ $\mathrm{cm}^{-1}, 1124 \mathrm{~cm}^{-1}$ and $1246 \mathrm{~cm}^{-1}$.

When basalt activated with the different concentrations of alkali solutions, different bands spotted to appear in the range from 1400 to $800 \mathrm{~cm}^{-1}$, Figures 5(a)-(c). The band deconvolution spectra for the basalt samples BS1, BS2, BS3 and BS4 cured at ambient temperature for 90 days are shown in Figure 5(a). For BS1 paste two double bands show in the spectra at $1150 \mathrm{~cm}^{-1} / 1099 \mathrm{~cm}^{-1}$ and 974 $\mathrm{cm}^{-1} / 894 \mathrm{~cm}^{-1}$. When concentration of activator increased the bands shift to
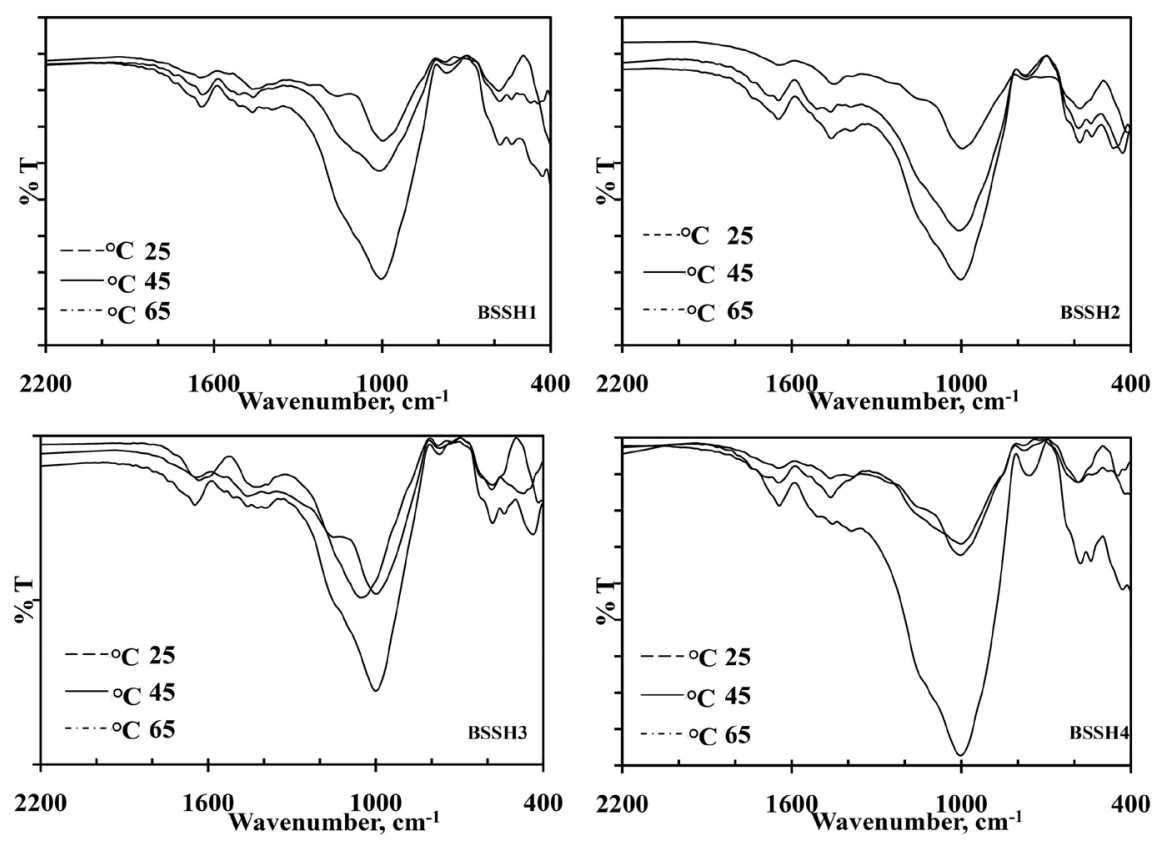

Figure 4. Infrared spectra of basalt-based geopolymer cured at different temperature for 90 day. 

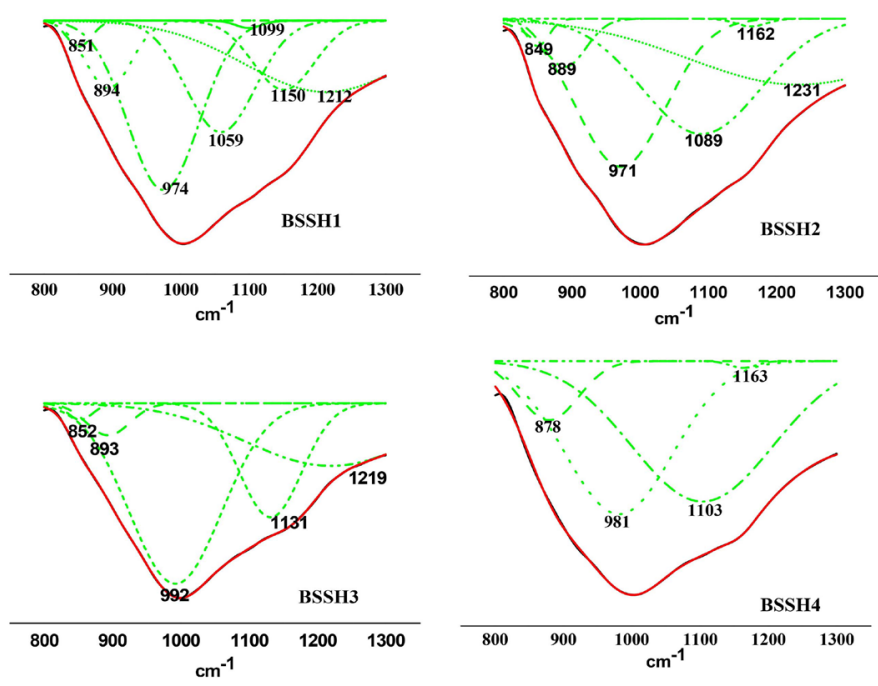

(a)
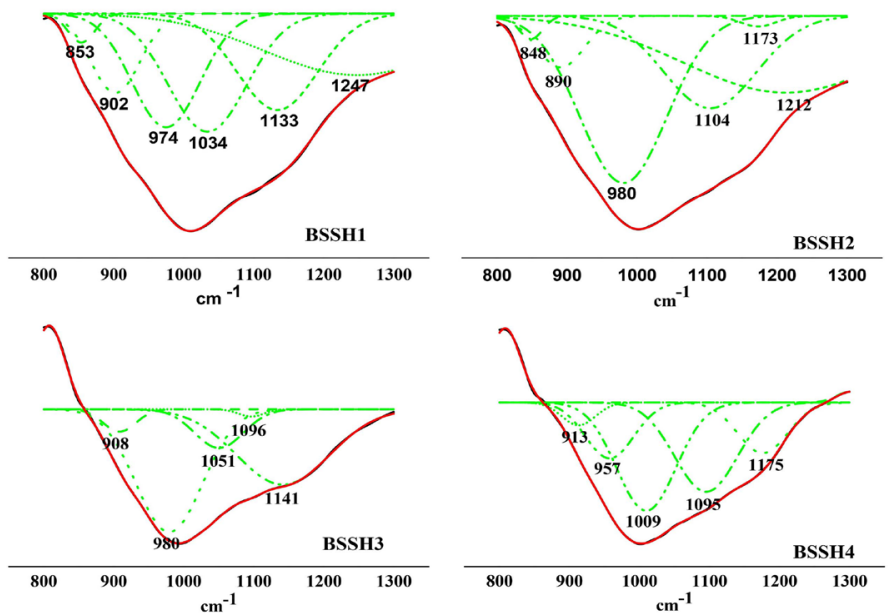

(b)
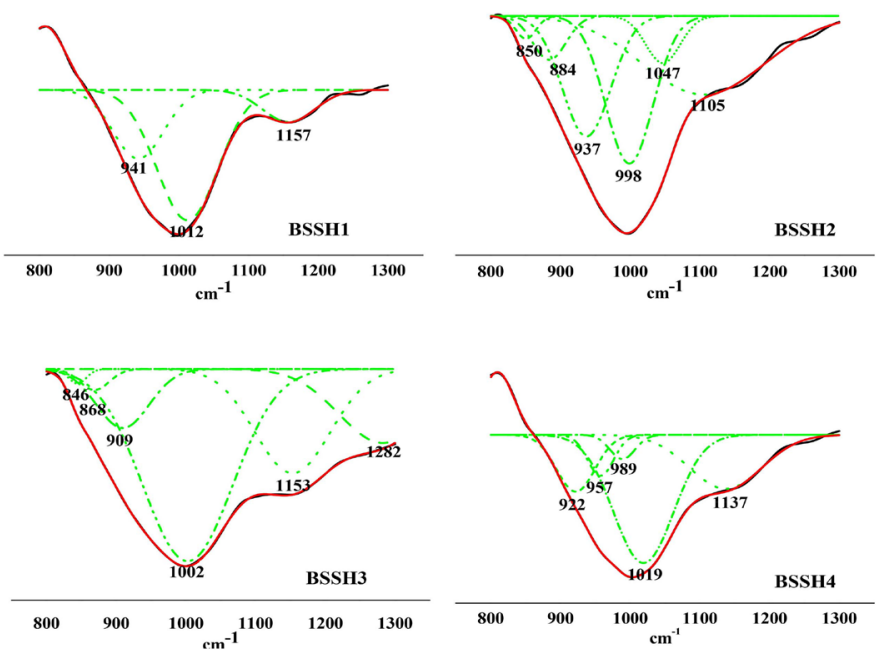

(c)

Figure 5. Deconvoluted spectra for the T-O bond asymmetric stretching band in basalt based-geopolymer cured at, (a) $25^{\circ} \mathrm{C}$; (b) $45^{\circ} \mathrm{C}$ and (c) $65^{\circ} \mathrm{C}$ for 90 days. 
lower wave number, $1103 \mathrm{~cm}^{-1} / 1089 \mathrm{~cm}^{-1}$ and $978 \mathrm{~cm}^{-1} / 878 \mathrm{~cm}^{-1}$. The shift in the Si-O-M peak indicates a higher class of geopolymer framework. In addition, Figure 4(b) shows the band deconvolution spectra for the basalt based geopolymers cured at $45^{\circ} \mathrm{C}$, up to 90 days. The main bands of basalt are appeared as double bands at $1009-1175$ and $853-975 \mathrm{~cm}^{-1}$. The bands at $848-890 \mathrm{~cm}^{-1}$ are due to $\mathrm{OH}$ bending in $\mathrm{Si}-\mathrm{OH}$ groups in the geopolymer networks, and these bands are changed basically both in intensity and in shape as a function of leaching time and temperature. The band at $957-980 \mathrm{~cm}^{-1}$ corresponds to $\mathrm{Si}-\mathrm{O}$ stretching in Si-O-Na structures, which formed by meeting of the alkali metal from the activation solution with the deprotonated centers in the relatively intermediate aluminosilicate structure. The bands at $1034-1247 \mathrm{~cm}^{-1}$ are consistent with the T-O-Si asymmetric stretching in the unreacted basalt. The deconvulation of IR spectra of basalt-geopolymer pastes cured at $65^{\circ} \mathrm{C}$ for 90 days are shown in Figure 5(c). The band $800-1400 \mathrm{~cm}^{-1}$ was splitted for two bands at $1137-1157$ and $998-1012 \mathrm{~cm}^{-1}$. The band related geopolymer became more sharp and narrow. If it is supposed that, the proportional areas of the resolved bands of unreacted basalt and new bands are related to their concentrations, Figures 6(a)-(c).

\subsection{The XRD Analysis}

Figures 7(a)-(d) shows XRD patterns of geopolymer samples BS1, BS2, S3 and BS4 cured at $25^{\circ} \mathrm{C}$ and $45^{\circ} \mathrm{C}$ for 1 and 90 days. After geopolymerisation all main characteristic peaks of minerals of basalt are remained, but their intensity were reduced with increased $\mathrm{Na}_{2} \mathrm{O} / \mathrm{SiO}_{2}$ ratio and increasing in curing time, Figure 7 . This suggests that the labradorite, augite and olivine as main phases in basalt did not dissolve totally into the gel phase. In geopolymerisation, once basalt is mixed with a sodium hydroxide solution, these pastes begin to transform into hard geopolymers. In such a situation, there is not enough time and space for the gel or paste to form a well crystallized structure such as in the case of zeolite formation. Although that the formed geopolymer actually consists of a number of amorphous and crystalline phases. Through the setting and hardening process, geopolymers are formed with strictly packed polycrystalline structure to give better mechanical properties than other crystalline phases, which have lower density, and cage-like crystalline structure. Basalt consist mainly of crystalline and some amorphous phases (as indicated by the hump, $5-102 \theta$ in XRD), Figure 7. This hump is due to the presence of amorphous phases. After the alkaline activation for the basalt-binder, Figure 7, this hump disappeared after 1 day. Based on the observation, it can be drawn that amorphous phase are highly reactive, whereas plagioclase (labardorite) has moderate reactivity with alkaline solution [39]. There is no appear new crystalline phase as a result of the alkali activation of basalt. On the other side, amorphous CSH in a geopolymeric gel could be main part of the resultant product.

Figure 8 illustrates the XRD patterns of prepared geopolymer, BS1, BS2, BS3 and BS4 cured at different temperature, ambient temperature, $45^{\circ} \mathrm{C}$ and $65^{\circ} \mathrm{C}$ for 


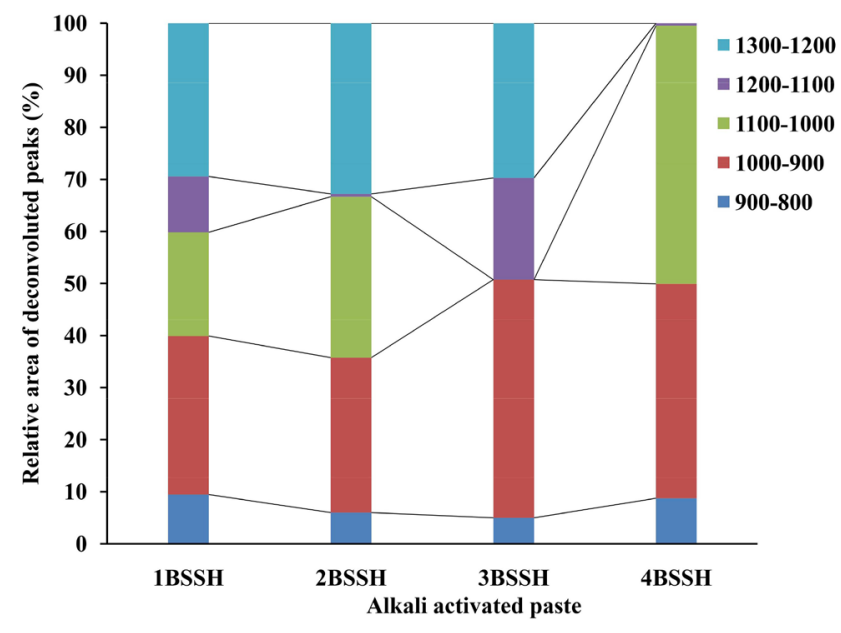

(a)

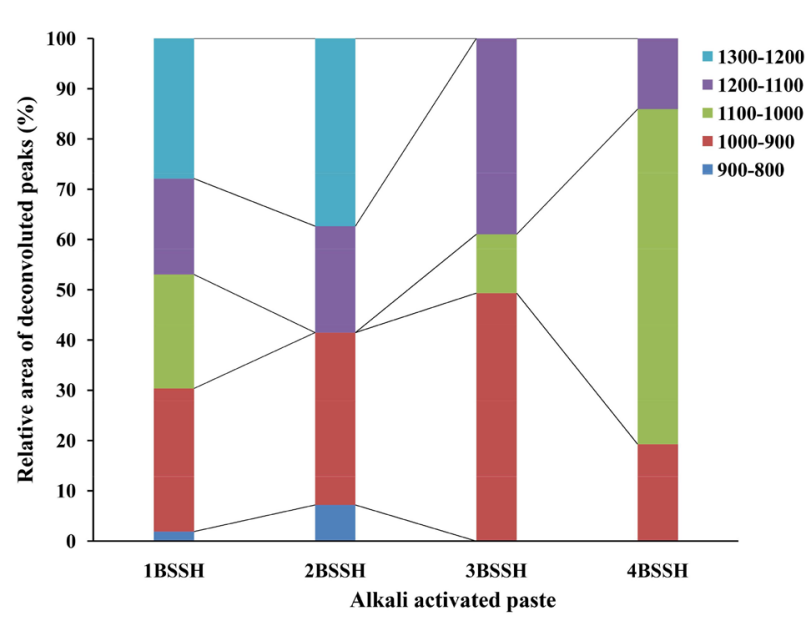

(b)

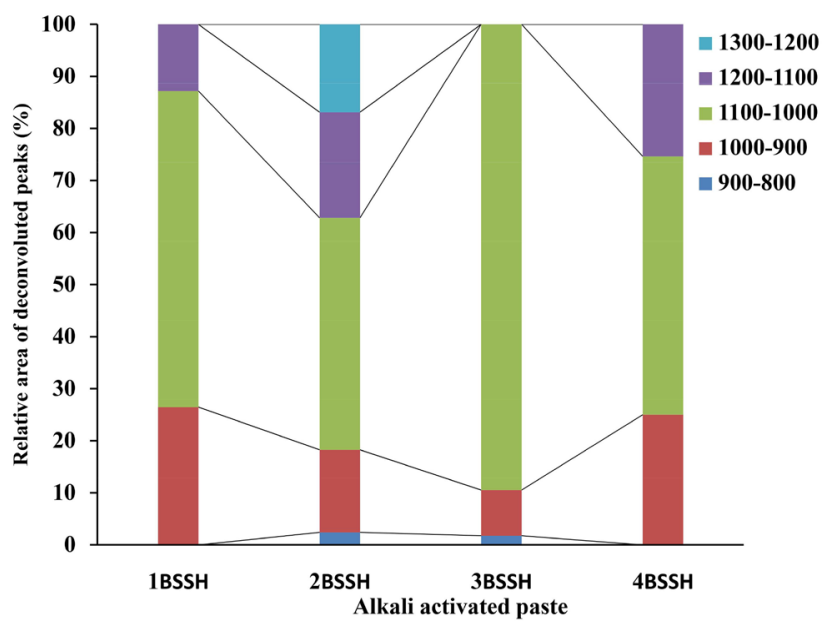

(c)

Figure 6. Relative area of the deconvoluted component peaks in the main Si-O-T vibration band region $\left(800-1400 \mathrm{~cm}^{-1}\right)$ in geopolymer samples cured at, (a) $25^{\circ} \mathrm{C}$; (b) $45^{\circ} \mathrm{C}$ and (c) $65^{\circ} \mathrm{C}$ for 90 days.

90 days. As seen from Figure 8, for all geopolymer samples the intensities of decreased with curing temperature except that of BS1. Also, the overlapped peak at $29.4-29.72 \theta$ of calcite and CSH became higher with curing temperature. This is indicating on the effect of temperature on the geopolymerization of basalt.

\subsection{Microstructure Analysis}

\subsection{1. (SEM-EDS) Characterization}

Figures 9(a)-(c) show the SEM images and EDX results of some selected geopolymer samples such as BS2 and BS3. As shows from EDX analysis most samples have composition suitable for geopolymerization is occur. Jaasveld et al. [40] were suggested the standard molar oxide ratio of $\mathrm{SiO}_{2} / \mathrm{Al}_{2} \mathrm{O}_{3}$ in geopolymer to be between 3.3 and 6.5 for product. Nevertheless, most of the selected spots in geopolymer binder have $\mathrm{Si} / \mathrm{Al}$ ratio in the range of $1-3$ and $\mathrm{Na} / \mathrm{Al}$ ratio around 1 , which is a typically range for geopolymer. The average atomic ratios were averaged of 6 different points in the geopolymer. 


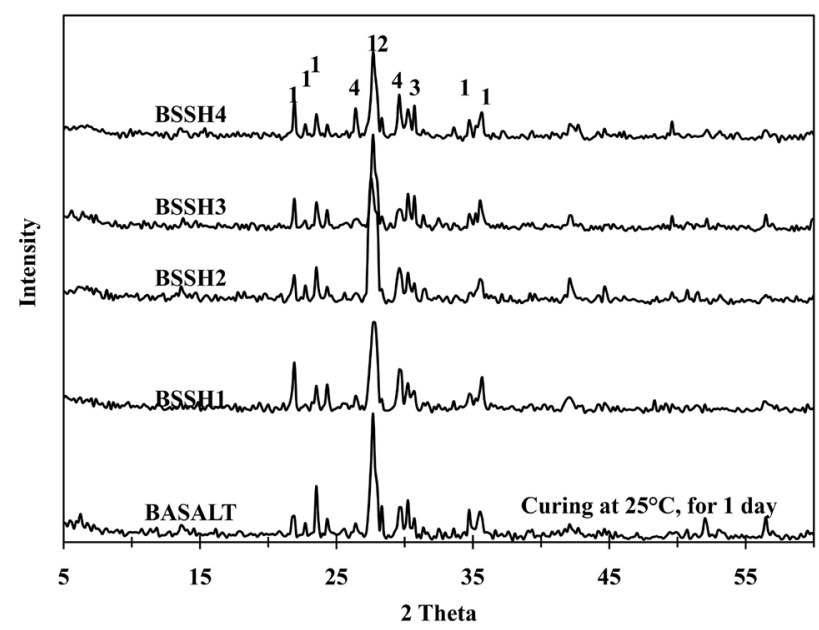

(a)

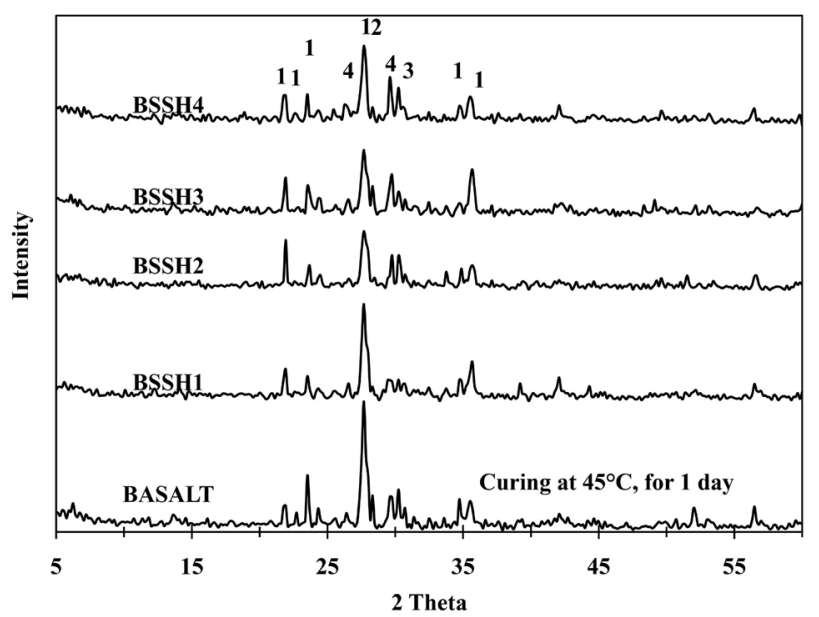

(b)

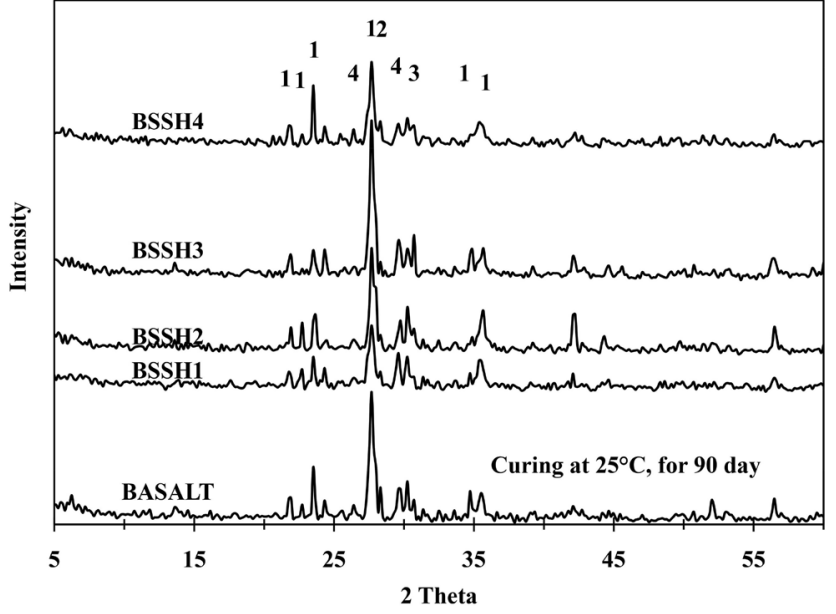

(b)

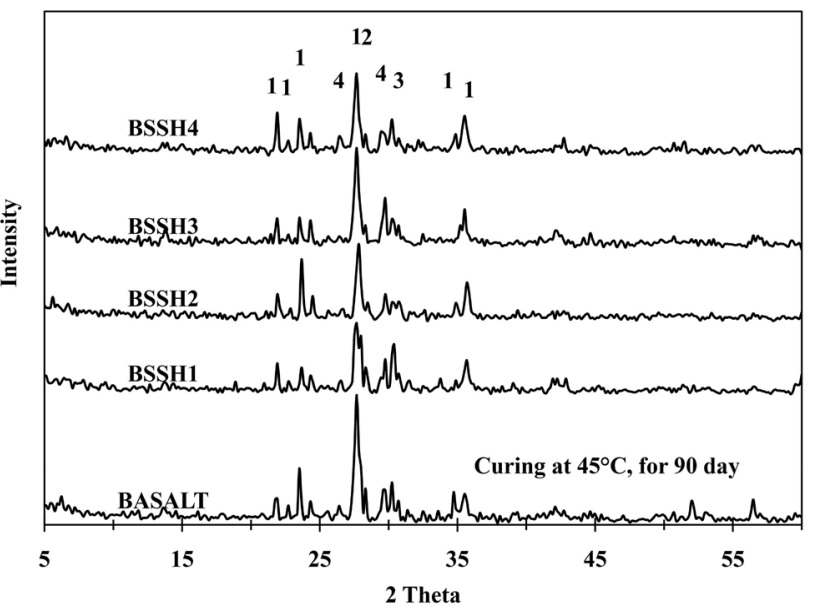

(c)

Figure 7. XRD patterns of basalt-based geopolymer cured at $25^{\circ} \mathrm{C}$ and $45^{\circ} \mathrm{C}$ for 1 and 90 day, whereas 1- Labradorite, 2- Augite, 3Olivine, 4- Calcium carbonate and 5- CSH.

The average atomic ratios for the reaction product of the BS2 sample, Figure 9(a), was cured at $25^{\circ} \mathrm{C}$, were $\mathrm{Si} / \mathrm{Al}=3.0$ and 1.55 , and $\mathrm{Na} / \mathrm{Al}$ ratios of 0.48 and 0.78. In addition, the average atomic ratios for the reaction product of the BS3 cured at ambient temperature were $\mathrm{Si} / \mathrm{Al}=2.16$ and 1.80 , and $\mathrm{Na} / \mathrm{Al}$ ratios of 0.5 and 0.82 . While that for basalt was $1.53-3.15$ and $\mathrm{Na} / \mathrm{Al}$ atomic ratio was 0.27 0.34 , confirmed the formation of strong geopolymer. The addition $\mathrm{NaOH}$ played a role in the attack of basalt-based geopolymer material leading to lower values of $\mathrm{Si} / \mathrm{Al}$ and increase $\mathrm{Na} / \mathrm{Al}$ ratios than the untreated basalt, due to the alkali roles for a suitable charge balancing resulting in a stable and dense geopolymer networks.

However, the predestined $\mathrm{Si} / \mathrm{Al}$ and $\mathrm{Na} / \mathrm{Al}$ ratios of some spots are much higher than the other sample. This might be because the detected areas in sample may consist of other components besides geopolymer gels, such as basalt particles with a $\mathrm{Si} / \mathrm{Al}$ ratio of $>3$, and zeolite crystals with a $\mathrm{Na} / \mathrm{Al}$ ratio of $>1.0$. 

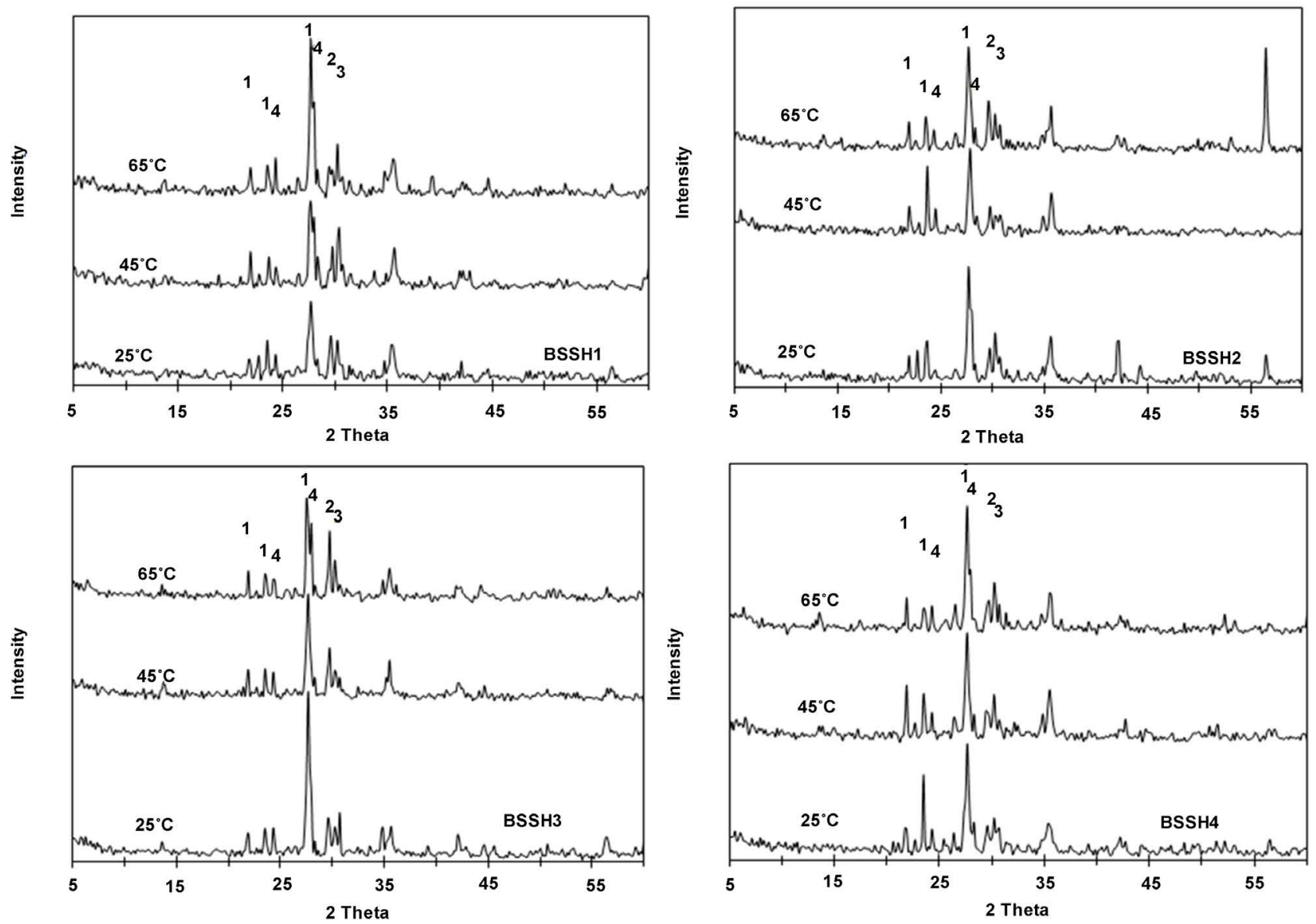

Figure 8. XRD patterns of basalt-based geopolymer cured at different temperature for 90 day, whereas 1- Labradorite, 2- Augite, 3- Olivine, 4- Calcium carbonate and 5- CSH.

When these geopolymer pastes, BS2 and BS3, cured at $45^{\circ} \mathrm{C}$, Figure $9(\mathrm{~b})$, the pastes appeared as a dense geopolymer matrix with a high strength than cured at ambient temperature. These matrix were showed atomic ratio $\mathrm{Si} / \mathrm{Al}=2.15-2.48$ and $\mathrm{Na} / \mathrm{Al}$ ratios of $0.1 .48-1.77$ and $\mathrm{Si} / \mathrm{Al}=1.82-3.82$ and $\mathrm{Na} / \mathrm{Al}$ ratios of $1.34-$ 2.50 for BS2 and BS3, respectively. In this case, the samples of the matrix with reduced $\mathrm{Si} / \mathrm{Al}$ ratios and the significantly raised $\mathrm{Na} / \mathrm{Al}$ ratios were identified.

On the other hand, curing at elevated temperature promoted the reaction of the geopolymer system and accelerate the conversion of oligomers in the geopolymer precursor to further condense and crystal like structure. The consumption of the oligomers triggered the release of more reactive $\mathrm{Si}$ - and Al-tetrahedra and generated more oligomers to participate in the geopolymerization and with difference $\mathrm{Si} / \mathrm{Al}$ and $\mathrm{Na} / \mathrm{Al}$ ratios.

Based on the EDX analysis of BS2 the estimated Si/Al molar ratios are 5.04, 2.52 and 2.3, and the estimated $\mathrm{Na} / \mathrm{Al}$ molar ratios are 2.14, 0.92 and 0.91 and for BS3, the estimated Si/Al molar ratios are 5.049, 2.52 and 2.29, and the estimated $\mathrm{Na} / \mathrm{Al}$ molar ratios are $2.149,0.929$ and 0.91 , respectively. The $\mathrm{Na} / \mathrm{Al}$ and $\mathrm{Si} / \mathrm{Al}$ ratios are similar between $\mathrm{BS} 2$ and $\mathrm{BS} 3$, which might be due to the similarity between that were produced. On the other hand, the $\mathrm{Si} / \mathrm{Al}$ and $\mathrm{Na} / \mathrm{Al}$ ratios of 

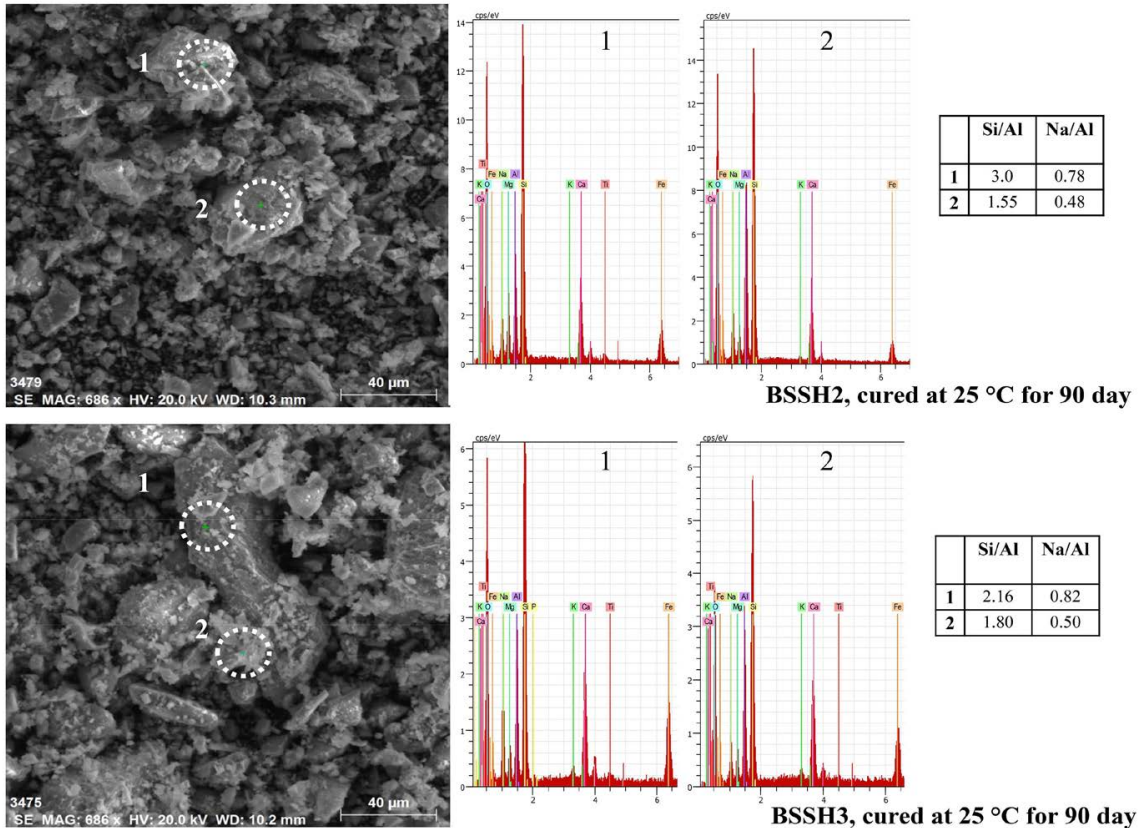

(a)
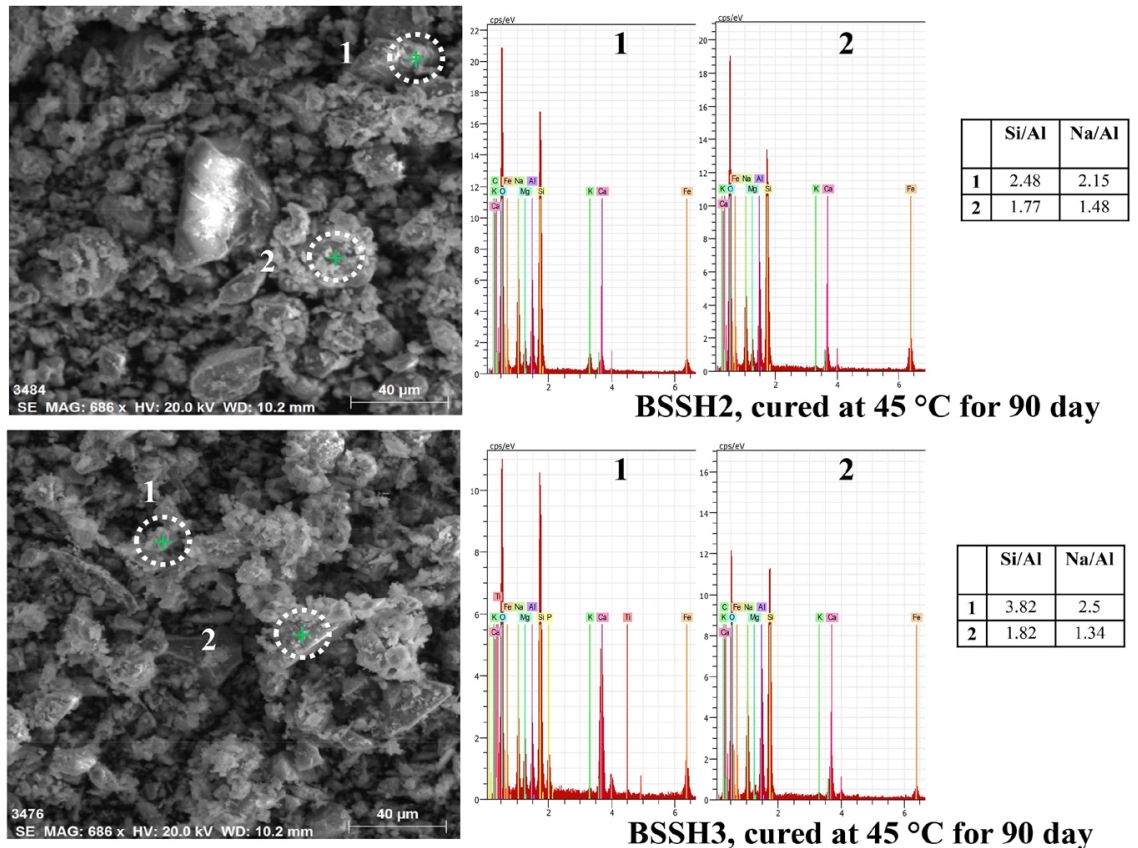

(b)

Figure 9. SEM-EDS analysis of basalt-based geopolymer, BSSH2 and $\mathrm{BSSH} 3$, (a) at $25^{\circ} \mathrm{C}$ for 90 day; (b) at $45^{\circ} \mathrm{C}$ for 90 days.

basalt are much higher than the other two samples. This might be because the detected areas in basalt sample may consist of other components besides geopolymer gels, such as basalt particles with a $\mathrm{Si} / \mathrm{Al}$ ratio of $>3$, and zeolite crystals with a $\mathrm{Na} / \mathrm{Al}$ ratio of $>1.0$. In addition, unreacted raw materials or non-reactive impurities and crystals with very different $\mathrm{Si} / \mathrm{Al}$ and $\mathrm{Na} / \mathrm{Al}$ ratios than those of geopolymer gels might affect these tested spots. 


\subsubsection{Scanning Electron Microscopy (SEM)}

Figure 10(a), Figure 10(b) show the microstructural characteristics as seen by SEM of the some geopolymer binder that obtained by alkali activation of a basalt cured at $25^{\circ} \mathrm{C}$ and $45^{\circ} \mathrm{C}$ for 90 day. When basalt was activated, the resulting material was an impermeable sticky gel. In addition, the samples studied have quite
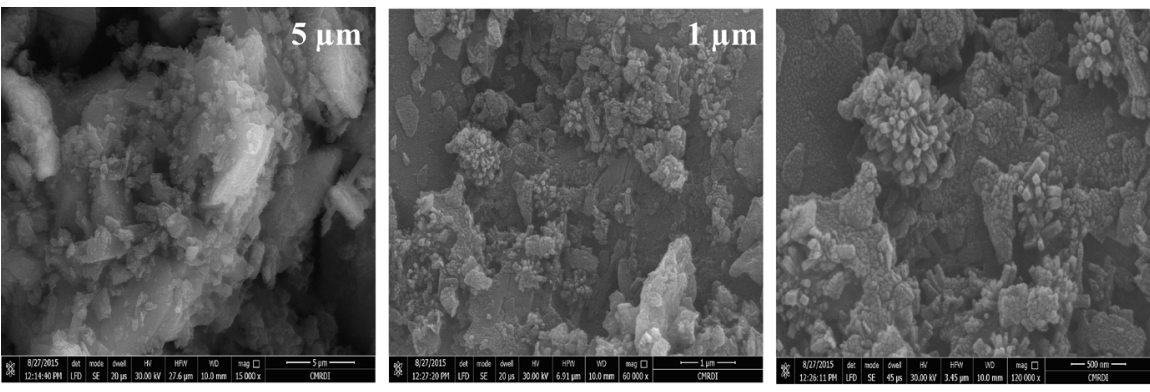

BSSH2, cured at $25-\mathrm{C}$, for 90 day
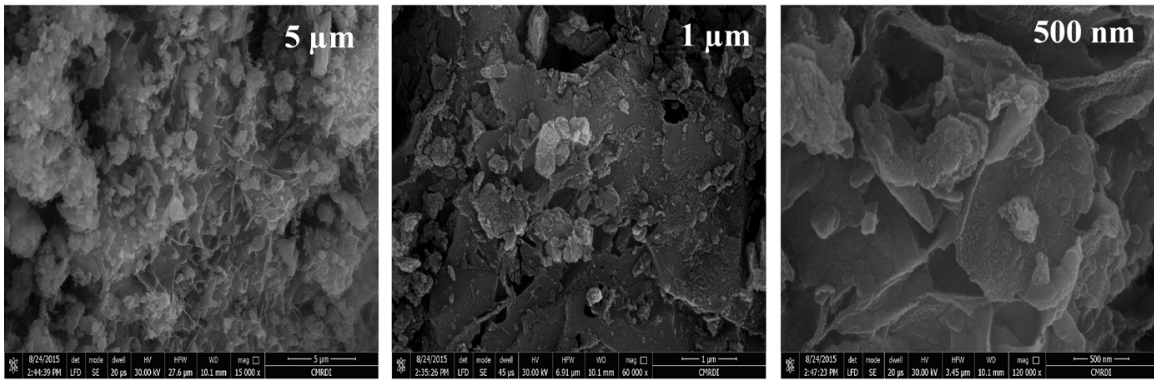

BSSH3, cured at $25-\mathrm{C}$, for 90 day

(a)
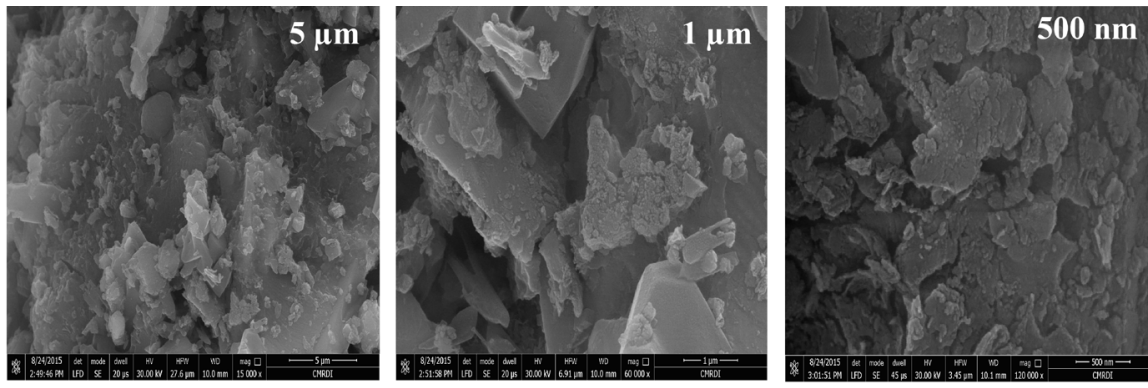

BSSH2, cured at $45-C$, for 90 day
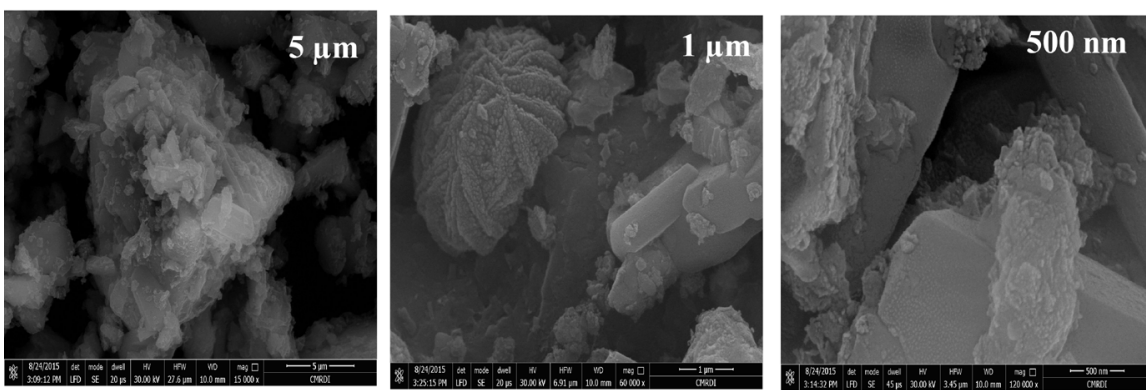

BSSH3, cured at $45-\mathrm{C}$, for 90 day

(b)

Figure 10. SEM micrographs analysis of basalt-based geopolymer, BSSH2 and BSSH3, (a) at $25^{\circ} \mathrm{C}$ for 90 day; (b) at $45^{\circ} \mathrm{C}$ for 90 days. 
different microstructures. From these SEM images, the residual basalt particles are almost all either embedded in voids or covered with loose gels connecting with the main geopolymer matrix. The binder obtained from the activation of BS2 and BS3 at ambient temperature are all visibly porous incompact microstructure, besides, the geopolymer has a flake-like layer structure similar to that of the basalt particulates and many partially reacted basalt particles remain. In addition, there are many corrosion craters on the reacting basalt surface, Figure. $10 \mathrm{a}$, but this appears more continuous and compact for the same mix at $45^{\circ} \mathrm{C}$, and with pore sizes reduced below the length scales visible in the micrograph. From this perspective, increasing compressive strength of BS2 and BS3 geopolymer paste cured at $45^{\circ} \mathrm{C}$ is related to enhancement the mechanical properties of formed gels as change their $\mathrm{Si} / \mathrm{Al}$ ratio [41] [42].

\section{Conclusion}

In this paper, geopolymers were synthesized successfully from basalt, via the alkali activation by sodium hydroxide solutions. The mechanical properties and microstructure of the resulting geopolymers are affected by multiple factors: curing temperature, curing time and chemical composition of mix composition. The curing at elevated temperature has improvement on the mechanical properties of basalt-based geopolymers. The XRD of different minerals of basalt are shown that the basalt reacted and dissolved with sodium hydroxide moderately and hence residue particles are placed as filler in the geopolymer matrices. The undissolved particles in the solution, could act as nuclei for geopolymerization reaction products. The interface of insoluble basalt particle/amorphous geopolymeric framework comprises the most sensitive area of the geopolymeric material. The $\mathrm{Si} / \mathrm{Al}$ and $\mathrm{Na} / \mathrm{Al}$ ratios of geopolymer gels estimated based on the EDS measurements are completely different from the nominal chemical composition of the untreated basalt. This is mainly attributed to dissolution and condensation reactions between different species during geopolymerization process. In future work, the activation of basalt by silicate anions and preparing of basalt-based geopolymer concrete are the main our target.

\section{References}

[1] Davidovits, J. (1991) Geopolymres-Inorganic Polymeric New Materials. Journal of Thermal Analysis, 37, 1633-1656.

[2] Uzal, B., Turanli, L. and Mehta, P.K. (2007) High-Volume Natural Pozzolan Concrete for Structural Applications. ACI Materials Journal, 104, 535-538.

[3] Davidovits, J. (2008) Geopolymers Chemistry and Applications. Institut Geopolymere, Saint-Quentin, France.

[4] Oh, J.E., Monteiro, P.J., Jun, S.S., Choi, S., Clark, S.M. (2010) The Evolution of Strength and Crystalline Phases for Alkali-Activated Ground Blast Furnace Slag and Fly Ash Based Geopolymers. Cement and Concrete Research, 40, 189-196.

[5] Provis, J.L. and van Deventer, J.S. (2007) Geopolymerisation Kinetics. 1. In Situ Energy-Dispersive X-Ray Diffractometry. Chemical Engineering Science, 62, 
2309-2317.

[6] Khale, D. and Chaudhary, R. (2007) Mechanism of Geopolymerization and Factors Influencing Its Development: A Review. Journal of Materials Science, 42, 729-746.

[7] Duxson, P., Fernández-Jiménez, A., Provis, J., Lukey, G., Palomo, A. and Van Deventer, J. (2007) Geopolymer Technology: The Current State of the Art. Journal of Materials Science, 42, 2917-2933.

[8] Liu, X., Ding, Y. and Lu, X. (2017) Immobilization of Simulated Radionuclide $90 \mathrm{Sr}$ by Fly Ash-Slag-Metakaolin-Based Geopolymer. Nuclear Technology, 198, 64-69. https://doi.org/10.1080/00295450.2017.1292810

[9] Fernandez, R., Martirena, F. and Scrivener, K.L. (2011) The Origin of the Pozzolanic Activity of Calcined Clay Minerals: A Comparison between Kaolinite, Illite and Montmorillonite. Cement and Concrete Research, 41, 113-122. https://doi.org/10.1016/j.cemconres.2010.09.013

[10] Boonjaeng, S., Chindaprasirt, P., Pimraksa, K. (2014) Lime-Calcined Clay Materials with Alkaline Activation: Phase Development and Reaction Transition Zone. Applied Clay Science, 95, 357-364. https://doi.org/10.1016/j.clay.2014.05.002

[11] Reig, L., Tashima, M.M., Borrachero, M.V., Monzó, J., Cheeseman, C.R. and Payá, J. (2013) Properties and Microstructure of Alkali-Activated Red Clay Brick Waste. Construction and Building Materials, 43, 98-106. https://doi.org/10.1016/j.conbuildmat.2013.01.031

[12] Temuujin, J., Williams, R.P. and Van-Riessen, A. (2009) Effect of Mechanical Activation of Fly Ash on the Properties of Geopolymer Cured at Ambient Temperature. Journal of Materials Processing Technology, 209, 5276-5280. https://doi.org/10.1016/j.jmatprotec.2009.03.016

[13] Lemougna, P.N., Melo, U.C., Delplancke, M.P., Rahier, H. (2014) Influence of the chemical and mineralogical composition on the reactivity of volcanic ashes during alkali activation. Ceramics International, 40, 811-820. https://doi.org/10.1016/j.ceramint.2013.06.072

[14] Barrie, E., Cappuyns, V., Vassilieva, E., Adriaens, R., Hollanders, S., Garcés, D. and Machiels, L. (2015) Potential of Inorganic Polymers (Geopolymers) Made of Halloysite and Volcanic Glass for the Immobilisation of Tailings from Gold Extraction in Ecuador. Applied Clay Science, 109, 95-106. https://doi.org/10.1016/j.clay.2015.02.025

[15] Tchakouté, H.K., Kong, S., Djobo, J.N.Y., Tchadjié, L.N. and Njopwouo, D (2015) A Comparative Study of Two Methods to Produce Geopolymer Composites from Volcanic Scoria and the Role of Structural Water Contained in the Volcanic Scoria on Its Reactivity. Ceramics International, 4, 12568-12577.

https://doi.org/10.1016/j.ceramint.2015.06.073

[16] Erdogan, S.T. (2014) Properties of Ground Perlite Geopolymer Mortars. Journal of Materials in Civil Engineering, 27, Article ID: 04014210. https://doi.org/10.1061/(ASCE)MT.1943-5533.0001172

[17] Khalifeh, M., Saasen, A., Vralstad, T., Larsen, H.B. and Hodne, H. (2015) Experimental Study on the Synthesis and Characterization of Aplite Rock-Based Geopolymers. Journal of Sustainable Cement-Based Materials, 5, 1-14. http://doi.org/10.1080/21650373.2015.1044049

[18] Tchadjié, L.N., Djobo, J.N.Y., Ranjbar, N., Tchakouté, H.K., Kenne, B.B.D., Elimbi, A. and Njopwouo, D. (2016) Potential of Using Granite Waste as Raw Material for Geopolymer Synthesis. Ceramics International, 42, 3046-3055.

https://doi.org/10.1016/j.ceramint.2015.10.091 
[19] Bondar, D., Lynsdale, C.J., Milestone, N.B., Hassani, N. and Ramezanianpour, A.A. (2011) Effect of Type, Form, and Dosage of Activators on Strength of Alkali-Activated Natural Pozzolans. Cement and Concrete Composites, 33, 251-260. https://doi.org/10.1016/j.cemconcomp.2010.10.021

[20] Xu, H. and Van Deventer, J.S.J. (2000) The Geopolymerisation of Alumino-Silicate Minerals. International Journal of Mineral Processing, 59, 247-266. https://doi.org/10.1016/S0301-7516(99)00074-5

[21] Xu, H. and van Deventer, J.S.J. (2003) The Effect of Alkali Metals on the Formation of Geopolymeric Gels from Alkali-Feldspars. Colloids and Surfaces A, 216, 27-44. https://doi.org/10.1016/S0927-7757(02)00499-5 https://s100.copyright.com/AppDispatchServlet?publisherName=ELS\&contentID=S 0927775702004995\&orderBeanReset=true

[22] Kani, E.N., Allahverdi, A. and Provis, J.L. (2012) Efflorescence Control in Geopolymer Binders Based on Natural Pozzolan. Cement and Concrete Composites, 34, 25-33. https://doi.org/10.1016/j.cemconcomp.2011.07.007

[23] Moon, J., Bae, S., Celik, K., Yoon, S., Kim, K.H., Kim, K.S. and Monteiro, P.J. (2014) Characterization of Natural Pozzolan-Based Geopolymeric Binders. Cement and Concrete Composites, 53, 97-104. https://doi.org/10.1016/j.cemconcomp.2014.06.010

[24] Korkanc, M. and Tugrul, A. (2005) Evaluation of Selected Basalts from the Point of Alkali-Silica Reactivity. Cement and Concrete Research, 35, 505-512. https://doi.org/10.1016/j.cemconres.2004.06.013

[25] Çopuroğlu, O., Andiç-Çakir, Ö., Broekmans, M.A. and Kühnel, R. (2009) Mineralogy, Geochemistry and Expansion Testing of an Alkali-Reactive Basalt from Western Anatolia, Turkey. Materials Characterization, 60, 756-766. https://doi.org/10.1016/j.matchar.2008.09.011

[26] Korkanç, M. and Tuğrul, A. (2004) Evaluation of Selected Basalts from Niğde, Turkey, as Source of Concrete Aggregate. Engineering Geology, 75, 291-307. https://doi.org/10.1016/j.enggeo.2004.06.015

[27] Unčík, S. and Kmecová, V. (2013) The Effect of Basalt Powder on the Properties of Cement Composites. Procedia Engineering, 65, 51-56. https://doi.org/10.1016/j.proeng.2013.09.010

[28] Laibao, L., Yunsheng, Z., Wenhua, Z., Zhiyong, L. and Lihua, Z. (2013) Investigating the Influence of Basalt as Mineral Admixture on Hydration and Microstructure Formation Mechanism of Cement. Construction and Building Materials, 48, 434-440. https://doi.org/10.1016/j.conbuildmat.2013.07.021

[29] Marfil, S.A., Maiza, P.J., Bengochea, A.L., Sota, J.D. and Batic, O.R. (1998) Relationships between $\mathrm{SiO}_{2}, \mathrm{Al}_{2} \mathrm{O}_{3}, \mathrm{Fe}_{2} \mathrm{O}_{3}, \mathrm{CaO}, \mathrm{K}_{2} \mathrm{O}$, and Expansion in the Determination of the Alkali Reactivity of Basaltic Rocks. Cement and Concrete Research, 28, 189-196. https://doi.org/10.1016/S0008-8846(97)00249-4

[30] ASTM C109/C109M-05 (2005) Standard Test Method for Compressive Strength of Hydraulic Cement Mortars (using 2-in. or [50 mm] Cube Specimens). ASTM International.

[31] Villa, C., Pecina, E.T., Torres, R. and Gómez, L. (2010) Geopolymer Synthesis using Alkaline Activation of Natural Zeolite. Construction and Building Materials, 24, 2084-2090. https://doi.org/10.1016/j.conbuildmat.2010.04.052

[32] Rovnaník, P. (2010) Effect of Curing Temperature on the Development of Hard Structure of Metakaolin-Based Geopolymer. Construction and Building Materials, 24, 1176-1183. https://doi.org/10.1016/j.conbuildmat.2009.12.023 
[33] Saraya, M.E.S.I. (2014) Study Physico-Chemical Properties of Blended Cements Containing Fixed Amount of Silica Fume, Blast Furnace Slag, Basalt and Limestone, a Comparative Study. Construction and Building Materials, 72, 104-112. https://doi.org/10.1016/j.conbuildmat.2014.08.071

[34] Onisei, S., Pontikes, Y., Van Gerven, T., Angelopoulos, G.N., Velea, T., Predica, V. and Moldovan, P. (2012) Synthesis of Inorganic Polymers using Fly Ash and Primary Lead Slag. Journal of Hazardous Materials, 205, 101-110. https://doi.org/10.1016/j.jhazmat.2011.12.039

[35] Álvarez-Ayuso, E., Querol, X., Plana, F., Alastuey, A., Moreno, N., Izquierdo, M. and Barra, M. (2008) Environmental, Physical and Structural Characterization of Geopolymer Matrixes Synthesized from Coal (co-) Combustion Fly Ashes. Journal of Hazardous Materials, 154, 175-183. https://doi.org/10.1016/j.jhazmat.2007.10.008

[36] Rees, C.A., Provis, J.L., Lukey, G.C. and van Deventer, J.S.J. (2007) Attenuated Total Reflectance Fourier Transform Infrared Analysis of Fly Ash Geopolymer Gel Aging. Langmuir, 23, 8170-8179. https://doi.org/10.1021/la700713g

[37] Bakharev, T. (2005) Geopolymeric Materials Prepared using Class F Fly Ash and Elevated Temperature Curing. Cement and Concrete Research, 35, 1224-1232. https://doi.org/10.1016/j.cemconres.2004.06.031

[38] Kani, E.N. and Allahverdi, A. (2009) Effects of Curing Time and Temperature on Strength Development of Inorganic Polymeric Binder Based on Natural Pozzolan. Journal of Materials Science, 44, 3088-3097. https://doi.org/10.1007/s10853-009-3411-1

[39] Celika, K., Jacksona, M.D., Mancioa, M., Merala, C., Emwasb, A.H., Mehtaa, P.K. and Monteiroa, P.J.M. (2014) High Volume Natural Volcanic Pozzolan and Limestone Powder as Partial Replacements for Portland Cement in Self-Compacting and Sustainable Concrete. Cement and Concrete Composites, 45, 136-147. https://doi.org/10.1016/j.cemconcomp.2013.09.003

[40] Van Jaarsveld, J.G.S., Van Deventer, J.S.J. and Lorenzen, L. (1997) The Potential Use of Geopolymeric Materials to Immobilize Toxic Metals: Part I. Theory and Applications. Minerals Engineering, 10, 659-669. https://doi.org/10.1016/S0892-6875(97)00046-0

[41] Lee, W.K.W. and van Deventer, J.S.J. (2002) The Effect of Ionic Contaminants on the Early Age Properties of Alkali-Activated Fly Ash Based Cements. Cement and Concrete Research, 32, 577-584. https://doi.org/10.1016/S0008-8846(01)00724-4

[42] Granizo, M.L., Alonso, S., Blanco-Varela, M.T. and Palomo, A. (2002) Alkaline Activation of Metakaolin: Effect of Calcium Hydroxide in the Products of Reaction. Journal of the American Ceramic Society, 85, 225-231. https://doi.org/10.1111/j.1151-2916.2002.tb00070.x 